\title{
Individual Factors on Ethical Decision Making by Tax Consultants in Bali
}

\author{
Cok Istri Ratna Sari Dewi ${ }^{*}$, Luh Putu Lusi Setyandarini Surya ${ }^{2}$, Cokorda Krisna \\ Yudha $^{3}$ \\ Universitas Warmadewa, Denpasar-Bali, Indonesia \\ \{coknanaa@gmail.com¹, lusisurya160@gmail.com², yudhacokkrisna@gmail.com³
}

\begin{abstract}
This study aims to determine the effect of idealism, professional commitment, and religiosity on tax consultant ethical decision-making. Tax consultants are often faced with ethical dilemmas that are influenced by individual factors, where they have to make a decision that is against the tax law and to comply clients' demands to maintain the sustainability of their business. This causes the tax consultant to consider an ethical decision to end the dilemmas. This study used 143 tax consultants who are certified and registered at Ikatan Konsultan Pajak Indonesia (IKPI) in Bali Branch as the research sample. The sample was determined using simple random sampling method. The data were analyzed using multiple linear regression analysis. The results showed that idealism, professional commitment, and religiosity has positive impact on ethical decision making by tax consultants in Bali.
\end{abstract}

Keywords: Ethical decision making; idealism; professional commitment; religiosity; tax consultant

\section{Introduction}

A tax is a compulsory charge imposed by the government and contributed by individual or corporate taxpayers without any expectation of direct return in benefit. Revenue from the tax sector is one of the highest sources of revenue in Indonesia, which is used to fund central and regional developments, such as education, developing public facilities, providing health care services and other state budget purposes. The tax revenues ratio in Indonesia decreased by 11,5 percent in 2018 to 10,7 percent in 2019 [1]. This phenomenon shows that the level of taxpayer compliance in fulfilling their tax obligations is still insufficient. Various efforts have been made by the government in increasing the realization of tax revenues, such as by implementing a self-assessment system. Self-assessment system is a tax system that gives taxpayers the authority to calculate, deposit and report the correct amount of tax from the income they have earned during a tax period or tax year. It can be said that the taxpayer can determine the amount of tax owed by themselves. The implementation of the self-assessment system in Indonesia has not been going well because it is difficult to implement the system from what have been expected and it is often misused by others [2],[3]. Complicated tax laws and regulations which continuously updated from time to time caused taxpayers encounter difficulties in keeping up with the tax regulations developments, including fulfilling their tax obligations that makes the role of a tax consultant is often indispensable. A tax consultant is a 
profession that offers its services to assist taxpayers in fulfilling their tax obligations in accordance with applicable laws and regulations. Taxpayers assume that a tax consultant must have extensive knowledges and insight so that by using their services, taxpayers can fulfill their tax obligations with the possible smallest amount money. The tendency of the taxpayer demand tax consultants services with the aim of reporting accuracy, to minimize taxes, fear of sanctions, including the reasons of insufficient time to fulfill their tax obligations [4]. However, on the other hand, various kinds of claims by taxpayers to tax consultants in fulfilling their tax obligations can affect the independence and credibility of the tax consultants. This can create a dilemma because taxpayers' claims usually have the potential to conflict with applicable tax regulations.

Tax consultants in providing their services have to deal with an ethical dilemma where they have to make a decision that is against the taxation laws and regulations that apply to client demands to maintain the sustainability of their service business. The idea of that dilemma is where tax consultants must comply with all the tax laws and regulations, but on the other hand, tax consultants also need to think about the reward or payment given by taxpayers and the continuity of their service business [5]. This causes tax consultants to consider an ethical decision to end a perceived dilemma. Indonesian Tax Consultants Association or Ikatan Konsultan Pajak Indonesia (IKPI) is one of the largest tax consultant associations in Indonesia, which consists of tax consultants who have a tax consultant practice license from the minister of finance Indonesia. Every IKPI member is obliged to maintain the image and dignity of the profession by complying IKPI code of ethics. Ethics is closely related to the relationship between individuals and use to direct each individual actions. The ethical dilemma faced by tax consultants confronts tax consultants to make a decision that is contrary to the principles of professionalism, and on the other hand, they also have to consider the material rewards from their clients [5]. Individual ethical decision-making will depend on individual factors [6].

One of the things that can help an individual facing ethical dilemmas is an ethical orientation. Ethical orientation is an alternative pattern of individual's behavior to resolve ethical dilemmas, which is formed by idealism [7]. An idealist attitude is defined as an attitude of being impartial and avoiding various concerns. Idealism is closely related to an individual's belief in something that is considered right which comes from experience, education, culture and habits that are guided by ethical and moral values. Tax consultants who have higher idealism level should be able to uphold the independence and integrity of their profession in terms of making ethical decisions, because they will not be easily tempted by rewards value. Ethical dilemmas can be resolved with professional commitment that contains loyalty to the profession that is owned by the individual [8]. Professional commitment is estimated by group support, positive attitudes towards the profession and job characteristics [9]. Professional commitment is a positive attitude towards the profession in maintaining the good name of the profession. Registered tax consultants at IKPI have their own code of ethics for controlling members in operating their activities. This is expected to lead tax consultants remain guided by ethical and moral values in making ethical decisions while maintaining association's reputation and its profession. One of the variables that affect tax compliance is religiosity, individuals who do not have involvement with their religion tend to see tax evasion as an acceptable thing [10]. Religiosity is the extent which a person is committed to religious teachings which are reflected in the attitudes and behavior. Strong religious belief expected could prevent illegal behavior through self-guilt, especially in the case of tax evasion [11].

Tax consultants who have higher religiosity level should be able to prioritize ethical decision making in all tax issues and ethical dilemmas when dealing with clients. Research on 
individual factors and their impact on ethical decision-making still gives inconsistent results that makes this interesting to do further investigation. Based on the issue that has been described previously, the problems that can be taken in this study are:

Does idealism affect tax consultant's ethical decision-making?

Does professional commitment affect tax consultant's ethical decision-making?

Does religiosity affect tax consultant's ethical decision-making?

\section{Method}

The population in this study were tax consultants in the Bali province. The sample of this study was tax consultants who are certified and registered at Indonesian Tax Consultants Association or Ikatan Konsultan Pajak Indonesia (IKPI) in Bali Branch. The sample was determine using simple random sampling method. Based on data from IKPI Bali branch, as of March 2020, the number of registered tax consultants was 223 people. Sampling in this study was measured using the Slovin formula and 143 respondents obtained as the research sample. This study used questionnaire method for collecting research data, several structured questions and statements with different indicators in each variable will be asked and measured by 5point Likert scale. Testing of the research instrument was done by testing the validity and reliability of the instrument, to discovered whether the research instruments and data in the questionnaire had been answered correctly or not, so that the research could obtain valid and reliable research results. A questionnaire is stated to be valid if the questions and statement on the questionnaire are able to reveal something as a research result. A variable is said to be reliable if the Cronbach Alpha value is more than 0.60 [12]. The data analysis technique in this study was done with statistical tests using multiple linear regression. Multiple linear regression analysis is used to determine or obtain an idea about the effect of independent variables on the dependent variable. Before testing the hypothesis using multiple linear regression models, the classical assumption test need to be taken first. The classical assumption test consists of several tests, namely normality test, multicollinearity test and heteroscedasticity test.

\section{Result and Discussion}

The results of the validity test show that all correlation coefficient values of the instruments are higher than 0.30 , therefore this research instrument can be said as valid. The results of the reliability test was done using the Cronbach Alpha statistical test. A variable can be said as reliable if the Cronbach Alpha value is higher than 0.60 [12]. The results of the reliability test show that all variables in this study have a Cronbach Alpha coefficient value higher than 0.60 thus the statements on the questionnaire are reliable. Classic assumption testing needs to be done so that the results of the regression analysis predictions are not biased and do not violate the assumptions of the least squares method or often called BLUE (Best Linear Unbiased Estimator). The classical assumption tests in this study including normality test, multicollinearity test, autocorrelation test and heteroscedasticity test. The results of the classical assumptions test in this study are presented in Table 1 
Table 1. Classical Assumptions Test Result

\begin{tabular}{lccc}
\hline \multirow{2}{*}{ Variable } & \multicolumn{3}{c}{ Classical Assumptions Test Result } \\
\cline { 2 - 4 } & \multicolumn{2}{c}{ Multicollinearity } & Heteroscedasticity \\
\cline { 2 - 4 } & Tolerance & VIF & Sig. \\
\hline Idealism & 0,301 & 3,319 & 0,668 \\
Professional & & 3,132 & 0,339 \\
commitment & 0,319 & 3,310 & 0,863 \\
Religiosity & 0,302 & \multicolumn{3}{c}{0,082} \\
\hline \multirow{3}{*}{ Normality } & $\begin{array}{c}\text { Asymp. Sig. } \\
\text { tailed })\end{array}$ \\
\hline
\end{tabular}

According to the test result on Table 1, the value of Asymp. Sig. coeficient (2-tailed) is 0.082 higher than 0.05 . The data is stated to be normally distributed if the Asymp. Sig. coefficient (2-tailed) is higher than 0.05 , thus it can be concluded that the variables in this study are normally distributed. The test results also showed that the independent variable has a tolerance coefficient higher than 0.10 , and VIF value less than 10 . This means that there are no multicollinear symptoms from the regression model, therefore the model is can be use to predict. The significance value of each variable in the heteroscedasticity test is higher than 0.05 , so that the research data can be said to be feasible and can be continued with multiple regression analysis.

Table 2. Multiple Regression Analysis Result

\begin{tabular}{|c|c|c|c|}
\hline Variable & $\begin{array}{c}\text { Regression } \\
\text { Coefficient ( } \beta \text { ) }\end{array}$ & $T$ & Sig. \\
\hline (Constant) & 0,780 & 3,528 & 0,000 \\
\hline Idealism (X1) & 0,300 & 7,370 & 0,002 \\
\hline $\begin{array}{l}\text { Professional } \\
\text { commitment (X2) }\end{array}$ & 0,110 & 3,589 & 0,009 \\
\hline Religiosity (X3) & 0,104 & 6,072 & 0,000 \\
\hline Adjusted R Square & & & 0,852 \\
\hline Sig. F & & & 0,000 \\
\hline
\end{tabular}

According to the multiple regression analysis result on Table 2, can be formed a regression equation as shown below:

$\mathrm{Y}=0,780+0,300 \mathrm{X} 1+0,110 \mathrm{X}_{2}+0,104 \mathrm{X}_{3}+\mathrm{e}$

The coefficient regression equation above indicates that the variables of idealism, professional commitment, and religiosity have a different effect on the dependent variable, which is ethical decision-making. The regression coefficient value of each variable such as idealism (X1) is 0.300 , professional commitment (X2) is 0.110 and religiosity (X3) is 0.104 . These results indicate that the variables of idealism, professional commitment, and religiosity have a positive effect on ethical decision-making by tax consultants at Indonesian Tax Consultants Association or Ikatan Konsultan Pajak Indonesia (IKPI) Bali Branch. In addition, the regression results also showed Adjusted R Square value is 0.852 which means that the effect of idealism, professional commitment, and religiosity on ethical decision-making is 85.2 percent, while the remaining of 14.8 percent is explained by other variables outside the research model. The $\mathrm{F}$ test aims to test the feasibility of a multiple regression model. If the 
significance value is less than 0.05 , it can be said that the research model is suitable to use. Based on the results of the analysis on Table 2, it can be seen that the significance value of $F$ is 0.000 or less than 0.05 , so it can be concluded that this model is suitable to use in this research.

The first hypothesis $\left(\mathrm{H}_{1}\right)$ in this study states that idealism has a positive effect on ethical decision-making by tax consultants. The results of hypothesis testing indicate that idealism has a positive effect on the tax consultant's ethical decision-making. Idealist attitude is defined as an attitude of being impartial and avoiding various interests. A tax consultant needs to maintain his idealism in carrying out his obligations in order to assist the government in increasing taxpayer compliance and increasing tax revenue realization. Tax consultants who have higher idealism level are expected to be able to uphold the independence and integrity of their profession in terms of ethical decisions-making, because they will not be easily tempted by rewards given by their client. Based on cognitive moral development theory [13] which is stated at the stages of moral development, goodness for society has been incorporated into individual's moral thinking. As much as possible, the tax consultant will make decisions in accordance with applicable regulations and try their best to not harm other parties, including the people who are their clients. The results of this study support the previous research result conducted by Harmana, et al. and Wirakusuma which states that idealism affects the ethical decision-making by tax consultants [14], [15].

The second hypothesis $\left(\mathrm{H}_{2}\right)$ in this study states that professional commitment has a positive effect on the tax consultant's ethical decision-making. The results of hypothesis testing indicate that professional commitment has a positive effect on the tax consultant's ethical decision-making. Commitment is a high job involvement which means taking sides with an individual's particular job [16]. Highly committed individuals will likely see themselves as true members of the organization. Professional commitment is estimated by support for groups, positive attitudes towards the profession and job characteristics [9]. Professional commitment is a positive attitude towards a profession to maintain the profession's reputation. Ethical dilemmas can be overcome with professional commitment that contains loyalty to the profession that is owned by the individual [8]. Professional commitment is a positive attitude towards the profession in maintaining the reputation of a profession. Registered tax consultants at Indonesian Tax Consultants Association or Ikatan Konsultan Pajak Indonesia (IKPI) have their own code of ethics in supervising members in carrying out their profession. This is expected to be able to make the tax consultant stick to ethical and moral values in making ethical decisions. They will be more careful in making decisions to maintain profession's reputation. The results of this study support the previous research result conducted by Abdurrahman and Yuliani, as well as Harmana, et al, who stated that professional commitment has a positive effect on ethical decision-making [14], [17].

The third hypothesis $\left(\mathrm{H}_{3}\right)$ in this study states that religiosity has a positive effect on the tax consultant's ethical decision-making. The results of hypothesis testing indicate that religiosity has a positive effect on the tax consultant's ethical decision making. Religiosity is the extent to which a person is committed to religious teachings which are reflected and can be shown from their attitudes and behavior. There is a difference between the terms religion (religion) and religiosity, where religion refers to formal aspects related to rules and obligations, meanwhile religiosity refers to aspects of religion that a person lives in their heart [18]. Religiosity is defined as the extent to which a person believes, observe everyday things from a religious point of view and applies his religious beliefs to everyday life [19]. In Indonesia, a person's religiosity has been taught since an early stage from family and school. The habit of obeying religious teachings will encourage someone to behave in accordance with religious teachings. 
Tax consultants who have higher religiosity level are considered to be able to prioritize ethical decision-making in all tax issues and ethical dilemmas when dealing with clients. The results of this study support the previous research result conducted by Riasmini et al, which shows that religiosity has a positive effect on ethical decision making [20], but it is different from research's result conducted by Massie [21] who found out that religiosity does not affect the tax consultant's ethical decision-making.

\section{Conclusion}

Tax consultants play an important role in assisting taxpayers in fulfilling their tax obligations in accordance with applicable tax laws and regulations. However, in practice, tax consultants in making decisions are often faced with ethical dilemmas. This study aims to determine the effect of individual tax consultant factors on ethical decision-making. From the research objectives, it can be concluded that the individual factors in this study, namely idealism, professional commitment, and religiosity have a positive effect on ethical decisionmaking by tax consultants in Bali. Registered tax consultants at Indonesian Tax Consultants Association or Ikatan Konsultan Pajak Indonesia (IKPI) have their own code of ethics in controlling members in operating their activities which is expected to be able to keep tax consultants guided by ethical and moral values in making ethical decisions. Based on the results of the research respondents' answers, it was found that idealism, professional commitment, and religiosity had a high average classification of answers. This means that tax consultants in Bali likely have a high idealism level and are committed to their profession, therefore they will be more careful in making an ethical decisions. They will consider moral values and positive attitudes towards the profession in maintaining their reputation as a professional tax consultant. In addition, in Indonesia, a person's religiosity has been taught since an early stage in terms from their family and school. The habit of obeying religious teachings will encourage someone to behave in accordance with religious teachings. Tax consultants who have higher religiosity level are considered to be able to prioritize ethical decision-making in all tax issues and ethical dilemmas when dealing with clients.

This study has limitations that can affect the results of the study. First, the conclusions of this research based on ethical decisions from registered tax consultants in Bali province only so that they cannot be generalized to all tax consultants in Indonesia. Secondly, this study used primary data obtained from the results of distributing questionnaires, without conducting direct interviews. There is a possibility that the answers of each respondent are biased because the respondents did not read the statements correctly and thoroughly. The suggestions that can be given for future research are to conduct research on other tax consultant associations in Indonesia, also possibly in other province, as well as add other factors that can influence tax consultant ethical decision-making.

\section{References}

[1] CNN Indonesia: DJP Ungkap Sebab Rasio Pajak Turun Jadi 10,7 Persen. https://www.cnnindonesia.com/ekonomi/20200211205100-532-473761/djp-ungkapsebab-rasio-pajak-2019-turun-jadi-107-persen. Access date: March 1st, 2020. 
[2] Tarjo and I. Kusumawati: Analisis Perilaku Wajib pajak Orang Pribadi terhadap Pelaksanaan Self Assessment System: Suatu Studi di Bangkalan. Jurnal Akuntansi dan Auditing Indonesia, 10 (1), 101 - 120 (2020)

[3] Zulkhaidi, Firman: Implementasi Self Assessment System Dalam Pemungutan Pajak Hotel di Kabupaten Karimun. Tugas Akhir Program Magister. Program Pascasarjana Universitas Terbuka (2017)

[4] Devos, K.: The Impact of Tax Professionals Upon the Compliance Behavior of Australian Individual Taxpayers, Revenue Law Journal, 22 (1), 1-26. (2012)

[5] Suardika, A. A. K. A.: Pengaruh Idealisme, Komitmen Profesional, dan Skeptisme Profesional pada Pembuatan Keputusan Etis Konsultan Pajak di Provinsi Bali (Doctoral dissertation, Universitas Udayana) (2015)

[6] Trevino, Linda Klebe: Ethical Decision Making in Organization: A PersonSituation Interactionist Model. Academy of Management Review. pp.601-617 (1986)

[7] Higgins and Kelleher: Comparative Perspectives on the Ethical Orientations of Human Resources, Marketing and Finance Functional Managers. Journal of Business Ethics. Vol.56, pp. 275-288 (2005)

[8] Larkin, J. M.: Does Gender Affect Auditor KAPs' Performance?. The Woman CPA. Spring pp. 20-24. (1990)

[9] Kwon, I. W. G., and Banks, D. W.: Factors Related To The Organizational And Professional Commitment Of Internal Auditors.Managerial Auditing Journal. Vol.19, pp.606-622. (2004)

[10] Stack, S., and Kposowa, A.: The effect of religiosity on tax fraud acceptability: A cross-national analysis. Journal for the scientific study of religion, 45(3), 325-351 (2006)

[11] Grasmick, H. G., Bursik Jr, R. J., dan Cochran, J. K.: Render unto Caesar what is Caesar's: Religiosity and taxpayers' inclinations to cheat. The Sociological Quarterly, 32(2), 251-266 (1991)

[12] Ghozali, Imam: Aplikasi Analisis Multivariate dengan Program SPSS. Semarang : Badan Penerbit Universitas Diponegoro (2012)

[13]Kohlberg, L.: Stage and Sequance: The Cognitive Developmental Approachto Socialization in D.A Goslin. Chicago: Rand McNally.Handbook of Socialization Theory and Research.pp. 347-480 (1969)

[14] Harmana, M.D., Wirakusuma, M.G. and Wirama, D.G.: Pengaruh idealisme, pengalaman, dan komitmen profesional pada pembuatan keputusan etis konsultan pajak terdaftar di wilayah bali-nusa tenggara. E-Jurnal Ekonomi dan Bisnis Universitas Udayana, 6, pp.3549-3578 (2017)

[15] Wirakusuma, M. G.: Pengalaman Memoderasi Pengaruh Idealisme dan Komitmen pada Keputusan Etis Konsultan Pajak di Wilayah Provinsi Bali. Jurnal Ilmiah Akuntansi dan Bisnis, 10-18 (2019)

[16] Robbins, R. W., and Wallace, W. A.: Decision support for ethical problem solving: A multi-agent approach. Decision Support (2007)

[17] Abdurrahman, A. and Laila Yuliani, N.,: Determinasi Pengambilan Keputusan Etis Auditor Internal (Studi Empiris Pada BUMN dan BUMD di Magelang dan Temanggung). Widya Warta, 35(2) (2012)[18] Risnawita, S, dan Ghufron, M.N.: Teori-teori psikologi. Yogyakarta: Arruzz media (2012)

[18]Kwon, O.: Buddhist and Protestant Korean Immigrants: Religious beliefs and socioeconomic aspect of life. New York: LFB Scholarly Publishing LLC (2003) 
[19] Riasmini, K., Herawati, N.T. and Kurniawan, P.S.: Pengaruh Gender, Tingkat Religiusitas, Dan Pemahaman Kode Etik Profesi Akuntan Terhadap Pembuatan Keputusan Etis Mahasiswa (Studi Empiris pada Mahasiswa Akuntansi Program S1 Universitas Negeri di Bali). JIMAT (Jurnal Ilmiah Mahasiswa Akuntansi) Undiksha, 9(1) (2020)

[20] Massie, J. M.: Pengaruh etika profesi, religiusitas, dan kompetensi terhadap pengambilan keputusan etis konsultan pajak (2017) 